DOI https://doi.org/10.36059/978-9934-588-41-9/1-19

\title{
ПЕРІОДИ ВІДРОДЖЕННЯ МОНУМЕНТАЛЬНОГО ЖИВОПИСУ УСПЕНСЬКОГО СОБОРУ КИЄВО-ПЕЧЕРСЬКОЇ ЛАВРИ (ХVІІІ-ХХІ СТОЛІТТЯ)
}

\section{Бардік М. А.}

20-й річниці відродження Успенського собору Києво-Печерської лаври присвячується

\section{ВСТУП}

У духовному житті українського народу та православних народів східнослов'янських земель найбільш відомим і шанованим храмом Богородиці, заступниці роду християнського, протягом століть був і залишається Успенський собор Києво-Печерської лаври. «Свята Боголіпна Небесіподібна Богородична церква кам'яна» ${ }^{1}$ - ці слова в «Печерському Патерику» увічнили красу як сутнісну характеристику про Успенський собору. Він був першою кам'яною церквою Печерського монастиря, його звели грецькі будівничі в $1073-1077^{2}(1078)^{3}$ pp. Живописне оздоблення виконали грецькі художники і руський іконописець, згодом преподобний Аліпій. Храм освятили в 1089 p.

Собор прикрашали мозаїки і фрески. До нашого часу збереглися невеликі фрагменти давніх мозаїчних і фрескових композицій, давньої підлоги, які експонуються в Національному КиєвоПечерському історико-культурному заповіднику (далі - НКПІКЗ). Храм i його художнє оздоблення було пошкоджено під час землетрусу 1230 р., татаро-монгольської навали 1240 р. Згідно 3 історичними джерелами, які, на жаль, не залишили свідоцтва щодо програми розписів та імен художників, а тільки короткі згадки про живописні роботи, відомо, що Успенський собор було розписано в 1470 р. зусиллями останнього київського князя Симеона Олельковича (живопис існував до вересня 1482 р. - руйнування

${ }^{1}$ Патерик Києво-Печерський / упоряд. І. Жиленко. Київ, 1998. С. 9.

2 Успенський собор. Києво-Печерська лавра - пам'ятка історії та культури Украӥни / Бруснікіна Г.П. та ін. Київ, 2006. С. 225.

${ }^{3}$ Асєєв Ю.С. Архітектура Київської Русі. Київ, 1969. С. 75-82. 
монастиря кримським ханом Менглі-Гіреєм); на межі XVI-XVII ст. поновлювалися розписи за князів Острозьких. Фасади Успенського собору в XVII-XVIII ст. прикрашали живописні композиції ${ }^{4}$. Численні перебудови змінили архітектурний вигляд собору; у 1690-х коштом гетьмана І. Мазепи храм набув барокових рис 5 . Тогочасне малярство загинуло під час пожежі 22 квітня 1718 р. - події катастрофічної, коли вогонь знищив дерев'яні будівлі верхньої території Лаври. Одначе Лавра, як і завжди, попри негаразди відродилась, і після пожежі було створено Лаврський архітектурний ансамбль у стилі українського бароко, що є окрасою Києва. Велика Успенська церква була відбудована й прикрашена стінописом, iї освятили в 1729 p.

Архівні матеріали і предмети музейних колекцій дозволяють визначити періоди відродження монументального живопису Успенського собору у XVIII-XXI ст. Це - мета дослідження. Його методологія грунтується на використанні загальнонаукових методів (аналіз і синтез, дедукція, емпіричне спостереження), історикокультурного та мистецтвознавчого аналізу для вивчення архівних документів, малюнків, фотографій живопису храму, його сучасних розписів.

\section{1. Барокова декорація та їі реконструкція у XVIII-XIX ст.}

Бароковий розпис, що прикрасив Успенський собор, віряни побачили в 1729 р. (його також датують $1722-1730$ pp ${ }^{6}$.). Про нього опосередковано можна скласти уявлення завдяки оновленню. Перший період відродження стінопису припадає на 1772-1777 pp., коли занепалі розписи написали заново. Для історії мистецтва цінним $\epsilon$ те, що перелік виконаних у той час композицій зберігався в лаврській бібліотеці. Відомо про два його варіанти: рукописи № 183 і № 204. Рукопис № 204 був опублікованийㄱ, а рукопис

4 Делюга В. Успенський собор Києво-Печерської лаври у світлі літературних та іконографічних свідчень XVII ст. Велика Успенська иерква Києво-Печерської лаври. Слід у віках : матеріали міжнар. наук. конф. (м. Київ, 1-2 жовтня 2001 р.) / НКПІКЗ. Київ, 2002. С. 37-43.

${ }^{5}$ Успенський собор. Києво-Печерська лавра... С. 231-235.

${ }^{6}$ Коренюк Ю. Успенський собор Києво-Печерської лаври: тези до історії художнього ансамблю, стародавньої та новітньої. Украӥнська художня культура: пам'яткоохоронні проблеми : зб. наук. пращь. Київ, 2011. С. 133.

${ }^{7}$ Истомин М.П. Описание иконописи Киево-Печерской Лавры. Чтения 6 Историческом обществе Нестора Летописиа (далее - ЧИОНЛ). 1898. Кн. 12. Отд. 2. С. 34-89. 
№ 183, більш докладний, знаходиться в Російській державній бібліотеці; його копія (далі - Опис) у 3-х примірниках зберігається в Інституті рукопису Національної бібліотеки України ім. В.І. Вернадського (далі - ІР НБУВ) ${ }^{8}$. В Описі міститься перелік і стислий опис композицій екстер'єру та інтер'єру, іконостасних ікон. В Описі зазначено, що в 1772-1777 pp. собор розписав начальник малярні, тобто іконописної майстерні, Захарія (Голубовський) зі своїми помічниками 9 . Ці розписи, виконані олією, оновлювали в першій половині XIX ст.

Другий період відродження храмового малярства відбувся за митрополита Серапіона (Александровського). Живопис, особливо зовнішній, поступово занепадав: зображення на фронтонах потьмяніли, у багатьох композиціях обличчя втрачені, тому в 1808 р. Лавра уклала контракт із дияконом подільської церкви Св. Миколая Набережного іконописцем Ємеліаном (Омеляном) Замислевським ${ }^{10}$. Він заново написав 105 композицій (до 500 облич): 46 - над головним входом і 32 - на фронтонах західного фасаду, 13 - на фронтонах південного фасаду, 14 - на фронтонах північного фасаду ${ }^{11}$.

Є. Замислевський виконував розписи за розпорядженням митрополита Серапіона: написати композиції саме таким гарним мистецтвом, яким вони до того були написані, під особливою та прискіпливою увагою начальника лаврських іконописців ієромонаха Захарії (Голубовського). Із таким куратором художник слідував первинним композиціям i колориту. В архівних документах немає відомостей про зміну програми розпису, тому тематико-сюжетні лінії оновлених розписів визначаються за Описом $^{12}$. Судячи 3 нього ${ }^{13}$ та малюнку К.П. Мазера художник увів у структуру декорації західного фасаду геральдичну композицію 3

8 ІР НБУВ. Фонд (далі - Ф.) І. Справа (далі - Спр.) 5411. ІР НБУВ. Ф. І. Спр. 5412. ІР НБУВ. Ф. І. Спр. 5413.

9 ІР НБУВ. Ф. І. Спр. 5412, аркуш (далі - арк.) 39, 39 зв.

10 Уманцев Ф. Матеріали до словника вітчизняних мистців, ремісників, керівників художніх робіт та меценатів XVIII - початку XX ст. (за документами архіву Києво-Печерської лаври). Студї мистецттвознавчі / ІМФЕ ім. М.Т. Рильського. 2008. Чис. 1 (21). С. 111.

11 (Центральний державний архів України, м. Київ - далі ЦДІАК України).

Ф. 128. Опис (далі - Оп.) 1 загальний (далі - заг.). Спр. 1234, арк. 3, 3 зв.

${ }_{12}^{12}$ ІР НБУВ. Ф. І. Спр. 5412, арк. 35 зв. -37.

${ }^{13}$ Там само, арк. 35 зв.-35а зв. 
2-ма ангелами, що тримали овальні медальйони; у медальйоні праворуч був зображений двоглавий орел - герб Російської імперії; ліворуч - герб захисника православ'я і покровителя Печерського монастиря князя К. Острозького ${ }^{14}$. На початку липня 1809 р. Є. Замислевський почав роботу, а 21 жовтня - закінчив, тобто, він виконав розписи 3 липня до жовтня $1809 \mathrm{p}^{15}$. Таким чином, Є. Замислевський не поновлював попередні розписи в 1808 р., як стверджувалося раніше ${ }^{16}$, а написав заново 105 композицій на 3-х фасадах собору (за винятком східного) в 1809 р.

Останній факт пояснюється архівними відомостями, в яких ідеться про поновлення київським іконописцем Степаном Сокольським 29 ікон на залізних дошках за вівтарем собору, тобто на його східному фасаді, з листопада 1797 р. до березня 1798 р. В лаврській малярні ${ }^{17}$.

Підкреслюємо, що зовнішній стінопис Успенського собору, атрибутоване нами ${ }^{18}$, не було, як вважалося раніше, розписом XVIII ст., який тільки поновлювали. Це - композиції, написані заново в $1798-1852 \mathrm{pp}$.

Аналізуючи за архівними джерелами види робіт, виконані художниками, маємо змогу стисло висвітлити розвиток декорації екстер'єру храму. У червні 1817 р. живописні роботи виконали художники Василь Яровський та його син Григорій з Києва, Пилип Тударєв із Василькова, Максим Кравцов з Обухова. Вони поновили композиції 3-х фасадів улітку 1817 р., а В. Яровський написав заново 29 композицій східного фасаду в другій половині 1817 p. ${ }^{19}$ У 1824 р. наново були написані композиції на барабані центрального купола, що засвідчив митрополит Свгеній (Болховітінов) ${ }^{20}$. Ці живописні роботи виконав київський іконописець Олександр Суховєєв: він написав зображення влітку 1824 р. За митрополита Філарета (Амфітеатрова)

${ }^{14}$ ЦДІАК України. Ф. 128. Оп. 1 заг. Спр. 2925, арк. 5, 5 зв.

15 ЦДІАК України. Ф. 128. Оп. 1 заг. Спр. 1234, арк. 3 зв., 9-13 зв.

16 Сіткарьова О. В. Архітектура Києво-Печерської лаври кінця XVIII-XX століття. Київ, 2001. С. 61.

17 ЦДІАК України. Ф. 128. Оп. 1 заг. Спр. 1039, арк. 2-9.

18 Бардік М. А. Оновлення монументального живопису Успенського собору Києво-Печерської лаври і Софії Київської в першій половині ХІХ століття : монографія. Київ, 2019. С. 77-81.

19 Бардік М.А. Вказ. твір. С. 81-82.

20 Болховітінов Євгеній, митрополит. Вибрані праці 3 історії Києва / упоряд., вст. ст. та дод. Т. Ананьєвої. Київ, 1995. С. 290. 
Г. Яровський виконав поновлення низки композицій упродовж серпня 1837 р. У січні - травні 1852 р. начальник лаврських художників ієромонах Іринарх заново написав зображення 24 старозавітних царів на металевих дошках для декорування барабана центрального купола Успенського собору ${ }^{21}$.

Протягом другого періоду також було проведено живописні роботи в інтер'єрі собору під керівництвом художника 3 Чернігівської губернії Іоакима Федоровича Юріна. Спочатку з ним уклали контракт на поновлення Великого іконостаса, іконостаса притвору, ікон та церковного начиння, роботи розпочали в грудні 1809 p. $^{22}$ Зміст робіт із монументальним живописом зафіксований в окремому контракті, укладеному 3 I. Юріним у липні $1810 \mathrm{p.}^{23}$ Вивчення змісту контракту дозволяє зробити висновок, що поновлення охоплювало головний вівтар, жертовник, Михайлівський вівтар, центральну частину, притвор та західні хори. Живопис очистили, заправили втрачені місця, вкрили оліфою.

Низку композицій І. Юрін оновив, їх, завдяки комплексному аналізу архівних матеріалів, ми атрибутували ${ }^{24}$, зокрема зображення в Михайлівському вівтарі, «Страсний цикл» у жертовнику, виконані влітку 1810 p.

У західних компартиментах були зображені ктитори благодійники Печерського монастиря, та його настоятелі - ігумени й архімандрити. Галерея була оригінальною частиною декорації собору. За контрактом I. Юрін заправив пошкоджені місця зображень настоятелів, а галерею ктиторів написав заново ${ }^{25}$. Отже, галерея ктиторів це - розписи I. Юріна, виконані в 1811 р. Маємо спростувати помилкову атрибуцію всієї портретної галереї як живопису Захарії (Голубовського) 1772-1777 рр. Така атрибуція була зроблена членами комісій, що в 1886 р. винесли вердикт про доцільність зміни розписів ${ }^{26}$. Авторство Захарії (Голубовського)

${ }^{21}$ Бардік М. А. Вказ. твір. С. 82.

${ }^{22}$ ЦДІАК України. Ф. 128. Оп. 1 заг. Спр. 1234, арк. 25, 30, 30 зв., 109-110, 125-128 зв.

${ }^{23}$ Там само, арк. 65-66, 74, 126-127.

${ }^{24}$ Бардік М.А. Вказ. твір. С. 85-99.

${ }^{25}$ ЦДІАК України. Ф. 128. Оп. 1 заг. Спр. 1234, арк. 126, 126 зв.

26 Петров Н. Об упраздненной стенописи великой церкви Киево-Печерской Лавры. Труды Киевской духовной академии (далее - ТКДА). 1900. № 4. С 581-583. Эртель А. Д. О стенописи великой Успенской церкви Киево-печерской лавры. ТКДА. 1897. № 4. С. 520-524. 
правильне тільки для галереї настоятелів. Ця помилкова атрибуція зображень ктиторів присутня в публікаціях XX-XXI ст., автори яких розглядали всю галерею Успенського собору як живопис XVIII ст. ${ }^{27}$ Уявлення про живопис, знищений у 1893 р., надають чорно-білі фотографії 3 колекцій НКПІКЗ і Національного художнього музею України (далі - НХМУ).

I. Юрін частково змінив композицію благодійників, прибравши деякі персонажі і додавши зображення українських гетьманів I. Скоропадського, Б. Хмельницького та I. Мазепи. Останніх, на жаль, у 1835 р. зафарбували ${ }^{28}$.

Роботи 3 монументальним живописом І. Юрін провів у 18101811 pр., після їх закінченні були встановлені поновлені іконостаси. Усі роботи 3 художнього оновлення інтер'єру собору було завершено в лютому $1812 \mathrm{p.}^{29}$

Другий період відродження живописної декорації Успенського собору, таким чином, припадає на 1809-1812 pp.

Пізніше, у $1821 \mathrm{p}$ та 1823-1824 pp., живопис промивали і заправляли в місцях втрат; у 1824 р. В. Яровський заново написав у Михайлівському вівтарі і жертовнику композиції «Бог Отець у славі» та «Знаряддя Страстей Христових»; у 1829-1830 pp. поновлювали розписи та ікони в головному вівтарі ${ }^{30}$.

Нами було уточнено авторство і датування нових розписів у нижніх приділах собору: св. первомученика архідиякона Стефана (I. Квятковський та I. Білецький, 1813-1814); св. пророка Іоанна Предтечі (І. Ороб'євський, 1827), св. апостола і євангеліста Іоанна Богослова (К. Волошинов, 1832)

Третій період відтворення монументального живопису за безперервності богослужінь у соборі, пов'язаний із діяльністю митрополита Філарета (Амфітеатрова) та лаврського художника Іринарха, датується 1840-1843 pp.

${ }^{27}$ Белецкий П. Украинская портретная живопись XVII-XVIII вв. Ленинград, 1981. С. 90. Ганзенко Л. Мальовання Успенського собору за джерелами XIII-XX століть. Пам'ятки Украӥни. 2003. № 1-2. С. 82-84. Жолтовський П.М. Монументальний живопис на Україні XVII-XVIII ст. Київ, 1988. С. 28, 29.

${ }^{28}$ ІР НБУВ. Ф. І. Спр. 5412, арк. 22а-23. ЦДІАК України. Ф. 128. Оп. 1 заг. Спр. 1824, арк. 6.

${ }^{29}$ ЦДІАК України. Ф. 128. Оп. 1 заг. Спр. 1234, арк. 108-110 зв.

${ }^{30}$ Докладніше див.: Бардік М.А. Вказ. твір. С. 95-99.

31 Там само. С. 99-104. 
У 1837 р. митрополит Філарет запропонував прикрасити розписами верхні приділи собору. Програму розписів верхніх приділів і стін над сходами, що вели на хори, розробив київський художник Олексій Стефановський (Олексій Флорович СенчилоСтефановський) у 1837 р., а затвердили іiі в 1838 р. До неї були включені і нові композиції, і старі (останні занепали, їх мали написати заново без будь-яких змін), оскільки виявилось, що всі верхні компартименти потребували ремонту i живописного оздоблення ${ }^{32}$.

До 1840 p. Лавра проводила торги i безуспішно шукала художника, який би взявся розписати верхні компартименти і додатково поновити в них усі іконостаси та іконостасні ікони. У 1840 р. зі Свенського монастиря Орловської губернії до Лаври за клопотанням митрополита Філарета був переведений художникчернець Іринарх, який виконував розписи, писав ікони, поновлював позолоту іконостасів. Іринарх узявся розписати (олійними фарбами) не тільки верхній ярус собору, а і нижній - весь основний об'єм храму (за виключенням східних апсид i нижніх приділів). Реалізувати такий серйозний задум одному художнику було неможливо, тому Лавра надала Іринарху 8 помічників, які виконували живописний послух і 3 хлопчиків-учнів ${ }^{33}$.

Іринарх виявив себе як талановитий художник-монументаліст: він виконував найвідповідальнішу частину живописної роботи, писав масштабні багатофігурні композиції у центральній частині храму, завбачливо зробив попередні малюнки, завдяки чому програма i художні особливості попередніх розписів було збережено, а також, як видатний організатор, він забезпечив увесь процес ремонтно-підготовчих та живописних робіт (вів фінансові розрахунки, вирішував питання виконання майстрами робіт і забезпечення необхідними матеріалами), а головне, зміг залучити і організувати потужний колектив художників і майстрів, які під його керівництвом надали монументальному живописному ансамблю Успенського собору нового життя. Ми ввели в обіг імена 48 художників (34 лаврських і 14 запрошених) і 26 майстрів, які працювали з Іринархом протягом липня 1840 р. - жовтня 1843 p. $^{34}$ Серед них - Іван Гудовський, котрий, як i О.Сенчило-

32 ЦДІАК України. Ф. 128. Оп. 1 заг. Спр. 1901, арк. 2-38 зв.

33 Там само, арк. 43-52.

${ }^{34}$ Бардік М. А. Вказ. твір. С. 121-125, 135-137. 
Стефановський, був другом Тараса Григоровича Шевченка. Останнім етапом живописних робіт керував академік Федір Солнцев. Створений під керівництвом Іринарха живопис існував до 1893 р. Збереглися всього кілька чорно-білих фотографій «Вселенських Соборів» (колекції НКПІКЗ і НХМУ). Слід зауважити, що Іринарх відродив лаврську живописну школу. Під його керівництвом розписували лаврські храми, золотили куполи церков і дзвіниць, писали і поновлювали ікони, зокрема в 18481849 pр. поновили Великий іконостас та іконостас притвору Успенського собору; імена 38 майстрів, що виконали цю складну роботу, ми ввели в науковий обіг ${ }^{35}$.

Після 1843 р. у соборі проводилися заходи реставраційного характеру, коли стінопис промивали від бруду і кіптяви, заправляли втрачені фрагменти. Серед них слід згадати роботи $1856 \mathrm{p.}^{36}$, 1869 p., 1873 p., 1891 p. $^{37}$ До кінця ХІХ ст. храмові розписи зберігалися без змін ще в досить свіжому вигляді ${ }^{38}$.

\section{2. Створення історичного образу храму в розписах кінця XIX і XXI століть}

Задовільний стан збереження стінопису Успенського собору, тим не менш, не задовольняв культурний та історичний запит суспільства, яке готувалося відзначити в 1888 р. доленосну подію 900-ліття хрещення Русі. Велика Лаврська церква, заснована в XI ст., була призначена явити у своєму художньому оздобленні живу пам'ять про утвердження православ'я.

Четвертий період відзначено втіленням ідеї відродити давньоруський образ храму в його стінописі, який виконали в 1894$1901 \mathrm{pp}$.

Цікаво, що сучасники називали нові розписи саме «реставрацією» (ми беремо слово в лапки, оскільки наукова реставрація передбачає збереження існуючого живопису), iii розуміли як повернення до живопису XI-XII ст. ${ }^{39}$ У 1886 p. розглядалося питання про поновлення розписів собору. Для прийняття остаточного рішення Лавра звернулася до Церковно-

${ }^{35}$ Бардік М. А. Вказ. твір. С. 125, 125, 138.

${ }^{36}$ ЦДІАК України. Ф. 128. Оп. 1 заг. Спр. 1700, арк. 75-84 зв.

37 Успенський собор. Києво-Печерська лавра... С. 241.

38 Лебединцев П. О возобновлении стенной живописи в великой Церкви Киево-Печерской лавры в 1840-1843 г. ЧИОНЛ. 1888. Кн. 2. С. 41.

${ }^{39}$ Савенко А. И. Великая церковь Киево-Печерской лавры. Киев, 1901. С. 7. 
археологічного товариства при Київській духовній академії. Були створені 2 комісії; їхній висновок був невтішним: визначалось, що живопис не має історичного та художнього значення, тому немає наукової перешкоди для його заміни. Найбільш вражаючим був висновок, що живопис собору своєю стилістикою, вибором тем, порядком розташування не відповідає давньому живопису, який мав бути у храмі в XI ст. ${ }^{40}$ Такий закид був абсурдним, адже художники на чолі 3 Іринархом не отримували завдання прикрасити Успенський собор за каноном ХІ ст. Члени комісій, які бачили нову програму розписів в дусі давньоруських і візантійських церков XIXII ст., рекомендували прикрасити собор мозаїками і фресками. Цю думку так і не втілили в життя.

Ідея нової декорації собору та розміщення низки композицій належала митрополитові Іоанікію (Руднєву). 3 урахуванням його розпоряджень професор живопису Василь Петрович Верещагін та архітектор, академік Семен Миколайович Лазарєв-Станищев розробили проект розписів, який було затверджено в травні 1894 p. $^{41}$ С. Лазарєв-Станищев мав зробити розбивку стін під живопис, включно 3 орнаментами, i контролювати підготовчі роботи. Контролем підготовчих робіт і виконанням орнаментів також займався В. Д. Фартусов. Основну частину робіт доручалося виконати В. Верещагіну, з яким у липні 1894 р. Лавра уклала контракт. Спочатку планувалося написати 262 композиції, пізніше їхня кількість збільшилася до $280^{42}$. Під керівництвом В. Верещагіна працювали 10 художників, серед яких був Г.І. Попов ${ }^{43}$. Останній через кілька років розписував лаврську церкву Преподобних Антонія і Феодосія Печерських з Трапезною палатою.

У головному квадраті Успенського собору, в жертовнику і дияконнику від верху до рівня хорів, а в головному вівтарі - майже до підлоги, живопис було виконано на золотому тлі; таке ж тло мали плафони верхніх приділів Преображення Господнього та Андрія Первозваного. Нижче карнизів, що йдуть по лінії підлоги

${ }^{40}$ Петров Н. Указ. соч. С. 579, 580.

${ }^{41}$ Савенко А. И. Указ. соч. С. 8.

42 Крайня О.О. До історії монументального розпису Успенського собору кінця XIX ст. Велика Успенська церква Києво-Печерської лаври. Слід у віках : матеріали міжнар. наук. конф. (м. Київ, 1-2 жовтня 2001 р.) / НКПІКЗ. Київ, 2002. C. 114.

${ }^{43}$ Савенко А.И. Указ. соч. С. 16. 
хорів, тло було виконано олійними фарбами із золотими вінчиками. У такий спосіб розписи, виконані олією, наближалися до сяйва мозаїчних композицій у візантійських храмах.

Для створення образу давньоруського храму в систему розписів собору були включені композиції, традиційні для візантійських і давньоруських церков XI-XII ст. Такими, наприклад, було зображення Христа Пантократора в центральному куполі, яке змінило «Новозавітну Трійцю», або «Таємна вечеря» в апсиді головного вівтаря замість «Розп'яття». Перелік головних композицій та їхня топографія були зафіксовані очевидцями подій ${ }^{44}$, пізніше систематизовано по компартиментах, зокрема у вигляді таблиці ${ }^{45}$. В основі тематико-сюжетних ліній була тема Богородиці, Її житія та уславлення. Серед провідних тем були сюжети Христологічного циклу, Страсного циклу, двонадесятих свят, заснування Успенської церкви, а також зображення Печерських преподобних і давньоруських святих. Останні певною мірою трансформували образ святості: замість знищеної галереї благодійників перед вірянами постали князі, які були прославлені не фінансовими внесками, а мученицькими подвигами і християнськими чеснотами.

6 серпня 1901 р. Успенський собор був урочисто освячений ${ }^{46}$. Для створення образу давньоруського храму також планувалася заміна барокових іконостасів, зокрема й Великого іконостаса. Проте іконостаси у візантійському стилі так і залишились у вигляді проектів. Великий іконостас «втримався», втративши, щоправда, верхні яруси.

Революційні події 1917 р., подальша агресивна політика атеїстичної влади, вилучення церковних цінностей, припинення на початку 1930 р. релігійного життя в Лаврі i, насамкінець, трагічна подія під час Другої світової війни - підрив 3 листопада 1941 р. - ці випробування принесло Успенському собору XX ст. Залишки розписів на руїнах храму були наочним свідоцтвом варварства, у безодню якого падає людина, утративши зв'язок із Богом.

Композиції, написані $\mathrm{B}$. Верещагіним та його помічникамихудожниками, для історії мистецтва не загинули. Вони були

${ }^{44}$ Савенко А.И. Указ. соч. С. 16-18.

45 Сіткарьова О.В. Успенський собор Києво-Печерської Лаври : До історії архітектурно-археологічних досліджень та проекту відбудови. Київ, 2000. C. 176 .

${ }^{46}$ Савенко А.И. Указ. соч. С. 36. 
зафіксовані на чорно-білих фотографіях. Частина з них знаходиться в колекції НКПІКЗ.

Після вибуху залишилися: південно-східний нижній приділ св. апостола євангеліста Іоанна Богослова, південна апсида, залишки стін апсиди головного вівтаря і північної апсиди, а також фрагменти стовпів. Роботи з розбирання руїн собору розпочали в 1946 р.; розчищення руїн у 1946-1948 pр. проводили під керівництвом В. Богусевича; у 1951-1952 pp., 1962-1963 рp., 19701971 pp. - розбирання та дослідження руїн було проведено під керівництвом М. Холостенка. У 1960-1970-х було здійснено консервацію залишків собору із вцілілим стінописом ${ }^{47}$. Здійснені науковцями археологічні та архітектурні обстеження стали основою для відбудови храму в майбутньому.

Ïї зазвичай пов'язують із виконанням Указу Президента України від 27.01.1996 р. № 20/96-рп «Про першочергові заходи щодо відбудови комплексу Михайлівського Золотоверхого монастиря та Успенського собору Києво-Печерської лаври у м. Києві», що є цілком справедливим. Але історичні факти дозволяють розширити загальнокультурний контекст відродження Успенського собору та усвідомити глибоку духовну необхідність, безальтернативність цього відродження. Ще за радянських часів за дорученням Ради Міністрів УРСР від 26.02.1980 р. № 28-363.7 Інститут «Укрпроектреставрація» 9.12.1981 p. розпочав розробку науково-дослідної і проектної документації по відтворенню собору. У листопаді був розроблений ескізний проект відтворення, який у цілому був схвалений, а потім удосконалювався. I вже 2.11.1986 р. на засіданні президії Науковометодичної ради міністерства культури СРСР доопрацьований ескізний проект отримав позитивну оцінку як такий, що відповідає Закону СРСР «Про охорону та використання пам'яток історії та культури» $^{48}$. Пожвавлення суспільної зацікавленості до КисвоПечерської лаври, вочевидь, обумовлювалось історико-культурним чинником: у 1982 р. святкували 1500-літній ювілей заснування Києва, а в 1988 р. - 1000-ліття хрещення Русі. Київ як колиска Давньоруської держави і православ'я посилив своє значення,

${ }^{47}$ Орленко М.І. Успенський собор Києво-Печерської лаври: методологічні засади та хронологія відтворення : монографія. Київ, 2015. С. 146, 147. Успенський собор. Києво-Печерська лавра... С. 250, 251.

${ }^{48}$ Там само. С. 88. 
значення України і Києво-Печерської лаври - центра духовної культури, сакрального мистецтва, осередка науково-просвітницької роботи і туризму. Успенський собор мав постати з руїн!

Цей амбітний і складний із точки зору архітектурного втілення проект було реалізовано в Україні, попри економічні негаразди 1990-х. Згаданий Указ Президента розпочав активну фазу відродження собору. Була розроблена і схвалена «Комплексна програма робіт із відтворення Успенського собору КиєвоПечерської лаври». Над розробленням проектної документації працював потужний колектив науковців (архітекторів, реставраторів, істориків, археологів, будівельників тощо) $з$ різних науково-дослідних установ, був опрацьований значний масив архівних матеріалів із зібрань архівів та музеїв України, до дискусії по питаннях зведення й художнього оздоблення собору долучились вчені, науковці, представники церкви і громадськості.

21 листопада 1998 р. відбулось закладання символічної капсули i першої цеглини, що ознаменувало початок відбудови Успенського собору. Храм звели у стислий термін: 24 серпня 2000 р. урочисто був відслужений чин освячення головного вівтаря Успенського собору. Собор повернувся до життя.

Ще на етапі розробки проектної документації дискусійним виявилося питання живопису храму. По-перше, частково зберігся розпис В. Верещагіна («Зішестя Святого Духа», фрагменти інших зображень), по-друге, знищений під час вибуху живопис можна було достовірно реконструювати на основі численних фото, а також відомого по літературних $\mathrm{i}$ архівних джерелах розташування сюжетів. Натомість була ухвалена «Концепція відтворення стінопису Успенського собору Києво-Печерської лаври» (автор Н. Сліпченко, Л. Ошуркевич, І. Сьомочкін), яка мала барокове ідейне підгрунтя: «Реконструкція лаврського стінопису у формах українського бароко (згідно 3 малюнками Ф. Солнцева та Програмою 1720-х рр.) дає унікальну нагоду реконструювати складну іконографічну концепцію київських православних богословів кінця XVII - початку XVIII століть і тим самим відтворити i показати нашим сучасникам важливий пласт тогочасної української культури, свідомо знищений наприкінці 
XIX ст.» ${ }^{49}$. Дві «опорні точки» не надійно фіксували ідейну вісь «Концепції». По-перше, під Програмою 1720-х автори мали на увазі згаданий вище Опис (рукописи № 183 і № 204), у якому вказано живопис, виконаний в 1772-1777 pp. По-друге, в акварелях 1843 р. Ф. Солнцев замалював композиції, написані під керівництвом Іринарха в 1840-1843 рр. (тільки розпис апсиди головного вівтаря, східної підпружної арки, галерея настоятелів була поновленим живописом 1770-х). Тому говорити про відтворення барокового живопису в Успенському соборі можна лише умовно.

Ми акцентували увагу, що Іринарх зробив малюнки первинних композицій, які в подальшому слугували основою для розпису собору. Схожий підхід у наш час застосували художникимонументалісти, розписуючи Успенський собор. Грунтуючись на акварелях Ф. Солнцева (замальованих в 1843 р. розрізах собору), архівних фотографіях, додатково запозичуючи взірці українського барокового мистецтва (зокрема фрагменти збереженого малярства Троїцької надбрамної церкви Києво-Печерської лаври), вони в цілому відтворювали храмовий живопис 1840-1843 pp.

Із барокового першовзірця храмової декорації були вилучені окремі композиції. Наприклад, «Розп'яття» ${ }^{50}$, первинно написане в апсиді головного вівтаря замінили традиційною для православних храмів сценою «Таємної вечері». У галерею ктиторів повернули зображення українських гетьманів i княгині-благодійниці, проте деяких із попередніх персонажів до нової декорації повертати не стали (приміром, Петра I). Принцип наслідування втілено в основному об'ємі собору. Знову перед очима віруючих постали масштабні композиції: сім «Вселенських Соборів» на стінах центральної нави і трансепта, сповнена просвітленої гармонії, молитовна сцена «Отче наш» на склепінні центральної нави, грандіозні зображення описаних в Одкровенні Іоанна Богослова апокаліптичних видінь «Поклоніння Господу двадцяти чотирьох старців» на склепіннях трансепта, «Новозавітна Трійця» і «Дев’ять чинів ангельських» у центральному куполі - ці та інші сцени в арках, на стовпах і склепіннях створюють образ барокової

49 Сліпченко Н., Ошуркевич Л., Сьомочкін I. Концепція відтворення стінопису Успенського собору Києво-Печерської лаври. Вісник інституту «Укрзахідпроектреставрація». 2000. Чис. 11. С. 101, 102.

${ }^{50}$ Там само. С. 102. 
декорації. Програма сучасних розписів формувалась за участі дирекції та науковців НКПІКЗ, намісника Лаври митрополита Вишгородського і Чорнобильського Павла (Лебідя).

Керівництво живописними роботами очолив В. Прядка, він також $\epsilon$ автором низки монументальних композицій та ікон для іконостасів. Над живописним оздобленням собору працював колектив відомих художників із різних регіонів України: Л. Дмитренко, Т. Дмитренко, А. Дмитренко, М. Дмитренко, М. Стороженоко, О. Владимирова, В. Пасивенко, А. Гончар, Л. Григорова, О. Григоров, В. Горецький, А. Тарнавський, В. Тарнавський, Є. Чернокозенко, Ю. Гузенко, С. Баяндін та ін.

Були виготовлені іконостаси, написані іконостасні ікони згідно з Описом, у художніх формах пам'яток барокової доби. Іконостас головного вівтаря, «нащадок» Великого іконостаса виконано в 1998-2000 pp. У подальшому іконостаси встановили в усіх бічних приділах. У приділі св. пророка Іоанна Предтечі, побудованого у вигляді 4-стовпного хрестовокупольного храму, іконостас має вигляд невисокої вівтарної перегороди на кшталт візантійських іконостасів. Цей невеликий храм у північно-західній частині собору нагадує про часи заснування Великої Печерської церкви.

П'ятий період відродження стінопису Успенського собору розпочався у 2000 p. і триває до нині.

3 січня 2013 р. був проведений чин освячення Успенського собору 3 відродженим живописом. Храм набув пишного оздоблення, гідного загальнонаціональній святині.

4 квітня 2015 р. був освячений відреставрований і розписаний приділ св. апостола євангеліста Іоанна Богослова, що в апокаліптичні часи нацизму й атеїзму унаочнював надію на відродження Успенського собору, укріплював віру у відродження Києво-Печерської лаври - центру православ'я.

\section{ВИСНОВКИ}

Монументальний живопис Успенського собору КиєвоПечерської лаври за майже тисячу років зазнав руйнівних впливів фізико-хімічних, механічних, соціальних чинників. Відсутність опалення, особливості кліматичних умов зі значними коливаннями температури i вологості, пожежі, руйнування призводили до псування та знищення розписів. Первісний стінопис собору - його 
мозаїки і фрески - загинули. Пошкоджений і втрачений стінопис доводилося відроджувати, інакше в соборі не могли б проводити богослужіння, адже благоліпний вигляд у символічній системі мислення християнина завжди асоціювався з образом краси Царства Божого на землі.

На церковний живопис впливав розвиток сакральної естетики. Критерії прекрасного мінялися із часом, згідно з ними змінювалося i суспільне замовлення на художне оздоблення храму. Так, у XVIII ст. живопис собору виконувався у бароковому стилі, у кінці XIX ст. створювався візантійсько-руський образ, а в XXI ст. було вирішено відродити бароковий образ.

Історичні джерела надають мало інформації про розпис собору до XVIII ст.: відсутні точні дати виконання стінопису, імена художників, сюжети композицій. Цих відомостей немає і в документах, де описані події, пов'язані з пожежею 1718 p. I подальшим відновленням собору. Тодішню барокову декорацію храму можна уявити завдяки відродженню монументального живопису, яке ми систематизували у п'ять періодів.

Перший період датується 1772-1777 pp. У цей час зовнішні та внутрішні розписи собору були заново виконані під керівництвом начальника лаврської іконописної майстерні Захарії (Голубовського). Тодішня програма розписів і стислі відомості про іконографію композицій були основою, по-перше, для уявлення декорації відбудованого після пожежі храму (1722-1729) i, подруге, для відродження монументального малярства в майбутньому.

Протягом другого періоду, у 1809-1812 pp., київським художником Є. Замислевським та чернігівським - I. Юріним були заново виконані розписи екстер'єру, низка - в інтер'єрі (зокрема, галерея благодійників Печерського монастиря, яка донедавна помилково вважалася живописом XVIII ст.), проведено поновлення (заходи реставраційного характеру) стінопису центральної частини i на хорах, іконостасів, ікон, начиння.

Другий і подальші періоди відродження храмового малярства відбувались за участі і під контролем митрополитів.

Третій період, який припадає на 1840-1843 pp., проведений талановитим художником i начальником лаврських живописців ієромонахом Іринархом, відзначено масштабними заходами 
з відродження всього монументального ансамблю собору (стінопис та комплекс іконостасів верхніх приділів).

На відміну від третього періоду, коли Іринарх ретельно дотримувався програми та іконографії попередніх розписів, четвертий період став часом відродження образу храму XI ст. часів Русі-України. Його в 1894-1901 рр. створювали художники під керівництвом В. Верещагіна.

П'ятий період, який розпочався в 2000 р., із року освячення відбудованого Успенського собору, і ще триває, як і четвертий, має спільну ідейну основу: відродити художній образ православної святині українського народу. Вона реалізована в художніх формах українського бароко. Основою сучасної декорації були опис декорації першого періоду і замальовки декорації третього періоду відродження. Сучасні художники застосували схожий з Іринархом підхід - працювати, грунтуючись на замальовках попередніх композицій.

Об'єднуючим чинником четвертого і п'ятого періодів, коли відроджували певний ідейно-художній образ храму, був вплив науковців.

\section{АНОТАЦІЯ}

В історії Успенського собору Києво-Печерської лаври, на тлі хроніки війн, пограбувань та благодійних справ можновладців, згадуються роботи 3 живописного оздоблення храму. У дослідженні розв'язана проблема систематизації живописних робіт, що проводилися починаючи 3 XVIII ст. і до наших днів. На основі аналізу архівних справ, свідчень очевидців, матеріалів музейних колекцій уперше виділено 5 періодів в історії живопису Успенського собору після пожежі 1718 р., коли головний храм Лаври набув барокових архітектурних і художніх форм. Виявлено вперше, що первинна система розписів визначається опосередковано - завдяки опису малярства, відродженого протягом першого періоду (1772-1777). Уперше виділено другий період, коли заново були написані композиції екстер'єру та інтер'єру собору (1809-1812). Простежені часткові зміни в оновленій храмовій декорації. Доведено суттєве значення третього періоду (1840-1843) як для збереження системи розписів у XIX ст., так і для реалізації відтворення стінопису собору художниками-монументалістами 
у XXI ст. Висвітлено спільний культурно-історичний чинник четвертого (1894-1901) і п'ятого (2000 р. - до сьогодні) періодів відродження живопису, попри зовнішню несхожість: під час четвертого періоду намагалися створити давньоруський образ храму як сутнісну ознаку православної святині часів Візантії і РусіУкраїни, а під час п'ятого періоду - бароковий образ як найбільш яскраве вираження самобутності української культури. Останні два періоди пов'язані з ювілеєм хрещення Русі. Акцентовано чинник впливу митрополитів (другий - п’ятий періоди) та науковців (четвертий - п'ятий періоди). У статті названі імена художників минулого, зокрема маловідомі в історії мистецтва. Серед них - друзі Т.Г. Шевченка. Указані також сучасні митці, завдяки яким Успенський собор здобув урочисте живописне оздоблення.

\section{ЛІТЕРАТУРА}

1. Асєєв Ю.С. Архітектура Київської Русі. Київ, 1969. 192 с.

2. Бардік М.А. Оновлення монументального живопису Успенського собору Києво-Печерської лаври і Софії Київської в першій половині XIX століття : монографія. Київ, 2019. 310 с. : іл.

3. Белецкий П. Украинская портретная живопись XVIIXVIII вв. Ленинград, 1981. 256 с. : ил.

4. Болховітінов Євгеній, митрополит. Вибрані праці з історії Києва / упоряд., вст. ст. та дод. Т. Ананьєвої. Київ, 1995. 488 с.

5. Ганзенко Л. Мальовання Успенського собору за джерелами ХІІІ-XX століть. Пам'ятки Украӥни. 2003. № 1-2. С. 70-91.

6. Делюга В. Успенський собор Києво-Печерської лаври у світлі літературних та іконографічних свідчень XVII ст. Велика Успенська церква Києво-Печерської лаври. Слід у віках : матеріали міжнар. наук. конф. (м. Київ, 1-2 жовтня 2001 р.) / НКПІКЗ. Київ, 2002. C. 37-43.

7. Жолтовський П.М. Монументальний живопис на Україні XVII-XVIII ст. Київ, 1988. 159 с. : іл.

8. Истомин М.П. Описание иконописи Киево-Печерской Лавры. ЧИОНЛ. 1898. Кн. 12. Отд. 2. С. 34-89.

9. ІР НБУВ. Ф. І. Спр. 5411.

10. ІР НБУВ. Ф. І. Спр. 5412.

11. ІР НБУВ. Ф. І. Спр. 5413. 
12.Коренюк Ю. Успенський собор Києво-Печерської лаври: тези до історії художнього ансамблю, стародавньої та новітньої. Українська художня культура: пам'яткоохоронні проблеми : зб. наук. прац̧ь. Київ, 2011. С. 104-193.

13.Крайня О.О. До історії монументального розпису Успенського собору кінця XIX ст. Велика Успенська церква КиєвоПечерської лаври. Слід у віках : матеріали міжнар. наук. конф. (м. Київ, 1-2 жовтня 2001 р.) / НКПІКЗ. Київ, 2002. С. 111-120.

14. Лебединцев П. О возобновлении стенной живописи в великой Церкви Киево-Печерской лавры в 1840-1843 г. ЧИОНЛ. 1888. Кн. 2. C. $34-42$.

15.Патерик Києво-Печерський / упоряд. І. Жиленко. Київ, 1998. $348 \mathrm{c}$.

16. Петров Н. Об упраздненной стенописи великой церкви КиевоПечерской Лавры. ТКДА. 1900. № 4. С. 579-610. № 5. С. 40-70.

17.Орленко М.I. Успенський собор Києво-Печерської лаври: методологічні засади та хронологія відтворення : монографія. Київ, 2015. $832 \mathrm{c}$.

18. Савенко А.И. Великая церковь Киево-Печерской лавры. Киев, $1901.41 \mathrm{c}$.

19. Сіткарьова О.В. Архітектура Києво-Печерської лаври кінця XVIII-XX століття. Київ, 2001. 338 с. : іл.

20.Сіткарьова О.В. Успенський собор Києво-Печерської Лаври : До історії архітектурно-археологічних досліджень та проекту відбудови. Київ, 2000. 232 с. : іл.

21.Сліпченко Н., Ошуркевич Л., Сьомочкін I. Концепція відтворення стінопису Успенського собору Києво-Печерської лаври. Вісник інституту «Укрзахідпроектреставрація». 2000. Чис. 11. C. 101-144.

22. Успенський собор. Києво-Печерська лавра - пам'ятка історії та культури України / Бруснікіна Г. П. та ін. Київ, 2006. С. 224-257.

23.Уманцев Ф. Матеріали до словника вітчизняних мистців, ремісників, керівників художніх робіт та меценатів XVIII - початку XX ст. (за документами архіву Києво-Печерської лаври). Студіï мистецттвознавчі / ІМФЕ ім. М.Т. Рильського. 2008. Чис. 1 (21). С. 102-129.

24.ЦДІАК України. Ф. 128. Оп. 1 заг. Спр. 1039.

25.ЦДІАК України. Ф. 128. Оп. 1 заг. Спр. 1234. 
26. ЦДІАК України. Ф. 128. Оп. 1 заг. Спр. 1700.

27. ЦДІАК України. Ф. 128. Оп. 1 заг. Спр. 1824.

28. ЦДІАК України. Ф. 128. Оп. 1 заг. Спр. 1901.

29. ЦДІАК України. Ф. 128. Оп. 1 заг. Спр. 2925.

30.Эртель А.Д. О стенописи великой Успенской церкви Киевопечерской лавры. ТКДА. 1897. № 4. С. 500-527.

\section{Information about author:} Bardik M. A., $\mathrm{PhD}$ in Study of Art, Leading Researcher at the Scientific-Research Department of the History and Archaeology National Kyiv-Pechersk Historical and Cultural Preserve

9, Lavrska Str., Kyiv, Ukraine 